Inaugurele rede Prof. Dr. Rainer Prokisch d.d. 20-12-2002

\title{
About the future fiscal constitution of the United States of Europe
}

\section{Introduction}

On 28 October 2002, the European Convention published the preliminary (or sometimes named "skeleton") draft of a Constitutional Treaty. It is certainly not astonishing that comments on the draft range between general consent, critical comments on the role the Union's institutions should play in future and total rejection, frequently with a negative comment like that the skeleton draft was "full of federalist waffle".

Nevertheless, the European Convention may indeed imply the founding of a real "state" that has by nature to be a federalist body. Certainly, the European federalism will never be so centralistic, as it is for instance the case in Germany. Between federalism and federalism, there can be enormous differences. It will be wise to consider Aristoteles' words: "Also for the size of states there is a natural limit as for other things like plants, animals or handicraft tools. All the things are loosing their natural effectiveness if they are too big or too small". This is nothing else than an expression of the subsidiarity principle how we find it written in Article 5 of the EC Treaty.

It is easy to speak about subsidiarity but is more difficult to concretise this principle. Therefore, the main question the writers of the convention are confronted with is, which powers should be allocated to the European Union and which powers should remain with member states, subnational entities and municipalities in order - to say it again with Aristoteles - "to make people happy".

However, in this respect one very often forgets the impact of financial resources on the allocation of powers. Constitutional competences have no value if the body does not dispose on the necessary resources. And resources are needed not only to do the 
minimum what a competence permits but also to be able to go beyond the minimum, i.e. to express political priorities, which go beyond compulsory expenditure.

Unfortunately, from a financial point of view it is still unclear whether the draft constitution adopts a new approach in respect of finances. Article 38 of the draft states that the Union budget is fully financed by "own resources". It further indicates that the article will set out the procedure for establishing the system of own resources. The words "own resources", however, do not imply automatically that the Union will be entitled in future to collect own taxes or charges (this was obviously what Renè de Groot meant when he spoke about "a lot of work"), which go beyond the existing system, which is substantially based on block grants from the treasuries of the Member States. It only remembers the already existing requirement of Article 269 of the EC Treaty: "... the budget shall be financed wholly from own resources". Article 2 of the Council Decision of 29 September 2000 on the system of the European Communities' own resources ${ }^{1}$ defines the term as including the traditional four types of revenues of the Union including intergovernmental contributions. There are writers, however, like the Dutch doyen of European Law Prof. Verloren van Themaat ${ }^{2}$ (who by the way wrote his dissertation about international tax law), who believe that the current system is not in consistency with Article 269 of the EC Treaty.

Nevertheless, Article 38 of the draft is not precise enough to conclude - at least not without doubts - that the system of own resources will be subject to reform. Also the second sentence of Article 38 of the draft convention leaves it open whether the system will be changed or not.

The question, therefore, arises whether the United States of Europe, comprising soon 25 states, will be able to proceed along the same old groove or whether it is necessary to find new ways of building up a fiscal constitution, in particular with own tax-raising powers of the Union. Of course, and I am assuming that the new constitution will consider it, the

2000/597/EC, Euratom, OJ L 253/42.

P. Verloren van Themaat, Pleidooi voor een Europese Vennootschapsbelasting, WFR 2002/6494, p. $1212 \mathrm{ff}$. 
handover of tax-raising powers to the Union presupposes that the members of the European Parliament will be able in future to decide on issues of government including raising taxes on the behalf of the European citizens. No taxation without representation.

\section{The present system of financing the European Union}

In order to get a picture about the new structure of a fiscal constitution we shoud first take a short look to the present system.

The 2002 general budget of the European Union totals about 100 million Euro in commitment appropriations. This corresponds to a little bit more than $1 \%$ of the gross production product (GNP) in the EU. A small ratio, we notice. The by far greatest part of appropriations is the one for agricultural expenditure, followed by the expenditure for structural operations what mainly includes the structural and cohesion funds. Appropriations for internal policies, external action and administrative expenditure are less than $20 \%$ of the whole budget.

The own resources of the Union are regularly divided into four types. Although the Luxembourg agreement of 21 and 22 April 1970 already provided that "own resources" should replace the Member States' contributions, the two most important revenues of the Union are still not really own resources but are made available to it by the Member States. The most important source of income is based on each member state's General National Product, it accounts for more than half the total of all resources. It is not only important because of its size but also because it serves as a buffer with a residual function to equate revenue and expenditure. However, we will see that it does not work as such a buffer what is certainly one of the most important shortcomings of the Unions's financing system. As a matter of principle, however, the size of GNP resources should be determined by the Union's budgetary requirements.

The second substantial resource is the so-called "Vat resource". Each country comprises a contribution from the product of value added tax levied at $0,75 \%$ on a harmonised base in 
2002; the rate will fall to $0,5 \%$ in 2004 which is the consequence of the so-called Berlin compromise. This compromise has shown that it is nearly impossible to come to a rational and objective agreement between member states when it comes to the question of financing the Union.

Real own resources, the so-called "traditional own resources", of the Union are the agricultural duties and sugar levies as well as the customs duties. In addition, there is a fifth source of income which is regularly found in he EU budget under the heading "miscellaneous" (e.g. tax paid by European civil servants) and is about 2\% of EU's total revenues, only.

Remarkable are two trends. First, over the last 15 years there was a decline in the relative contribution of the traditional own resources, whose share has fallen from about $30 \%$ of the total in 1988 to about $15 \%$ nowadays. Second, there was a clearly visible decline in the share of VAT contributions from almost $70 \%$ of total resources in 1990 to about $35 \%$ in 2001. Correspondingly, the share of the GNP resources has risen to more than $50 \%$ of the total. This change has certainly attributed to better equity of gross contributions of the Member States, as the contributions on the VAT resource are regressive since they represent a higher proportion of GNP in poor rather than rich Member States.

This system of financing the competences of the Union allows member states to limit the expenditure of the Union, restricting at the same time the political ambitions of the Union's institutions. The level of the resources is fixed in a Council decision adopted unanimously, which has additionally to be ratified by the national parliaments. The Union's budget is further not permitted to show a deficit, it has to be financed wholly from own resources (Article 269 EC). In a situation where financial resources are not sufficient to balance the budget, the Union's institutions together with the Member States have to ensure that either less money will be spent or the income of the Union increases. In practice, however, both alternatives are very difficult to achieve. A reduction of expenditure is hardly possible within the existing system of the Union's competences as the predominant part of the budget is already locked up in favour of obligatory duties. On 
the income side the problem is obvious. It can be hardly expected that it is possible to achieve every year an agreement between member states to provide higher resources in order to finance the Union's budget.

Furthermore, the system facilitates political motivated decisions deviating from the principle of equity in respect of Member States gross contributions. The most striking example for an unsystematic deviation from the principal that each member state should contribute to the Union's resources equally according to its "ability to pay" is the correction mechanism in favour of the United Kingdom. If this mechanism remains unchanged, the United Kingdom would pay only one third of what it would otherwise be obliged to pay, under consideration of the forthcoming enlargement.

In addition, the Union's annual budget has to be drawn up in conformity with a mediumterm financial framework laying down annual expenditure limits. In context with the Agenda 2000, a financial perspective for seven years was adopted; it covers the period until 2006. During the period of preparations of the Agenda 2000 the dependence on intergovernmental transfers has already contributed to severe conflicts. The compromise of Berlin only looks like as if there was a real solution found. Without having a second sight one may predict that the financial questions within the preparation of the financial perspective beyond 2006, then with other ten member states, will equally contribute to conflicts which will even question the Union as such.

Generally spoken we can summarize that the current system of financing the Union's budget is incompatible with the principle of subsidiarity and the requirement that there should be a direct link between European citizens (who are at the same time taxpayers, what we should not forget) and the European budget. 


\section{General principles of the future fiscal constitution of the Union}

Can we do better? I believe yes. If we are prepared to make the Union more democratic and if we forget all those tensions and exaggerated sorrows about national sovereignty (which are frequently only an imagination considering the fact that also in the field of taxation the national legislators are not independent anymore) it should be possible to write a new fiscal constitution of the Union. It is important in this context that we learn from the shortcomings of existing federal systems. You will understand that I am primarily thinking in the German constitution.

\section{Constitutional issues}

Any fiscal constitution within a federal state is confronted with five basic questions.

(1) How are powers divided between the federation and members?

(2) What financial impact have these powers (financial evaluation of the powers)?

(3) How will the financial resources divided between federation and members in order to finance adequately the competences of the federation and members?

(4) Which kind of resources are used to finance the share of the federation?

(5) Should there be some kind of equalisation payments between the members and/or between the federation and financially weaker members.

\section{a) Division of powers}

Starting point of any considerations in respect of the issue how the future fiscal constitution of the Union should look like is the question which competences the Union will have in future. Only on ground of this system of division of powers we are able to estimate how much money is needed to fulfil functions in an appropriate way.

The convention draft is still quite vague in respect of determining the competences of the Union. The first sentence of Article 8 establishes the principle that any competence not conferred on the Union by the constitution rests with the member states. Articles 10 to 13 
differ between certain categories of competences. The intention is to formulate exclusive competences of the Union, competences where the Union and the member states share powers (however, the Union shall have the ability to take action within those areas excluding member states from acting outside the limits defined by the Union) and other areas where the Union is allowed either to act in support or in order to co-ordinate member states' actions or where member states are free to formulate common policies within the framework of European law.

Thus, we still do not know which competences will finally be conferred on the Union. The only requirement we can formulate is that - to say it in a more economical way European competences should provide for European public goods; or in a more juridical way: the Union should have those competences which cannot be exercised anymore alone by the member states. And those European public goods should then - according to the theory of public finance but also on ground of democratic principles - be financed by the Union itself.

One could argue that it is not necessary that the financial responsibility follows the material competences of the Union. Such a functional separation of powers we find within the federal system of Germany. There the members of the federation carry the financial burden if they are responsible for implementing a certain policy even if the policy as such - but also the financial consequences - are determined by the federation. This is possible because - in theory - any decision of the federation which results in a higher financial burden of the Länder is adjusted automatically by a new allocation of the resources of the whole state body. In my view, it would not be recommendable to introduce such a system to the European Union. In Germany the system never worked adequately. It is quite common that the German federal government makes decisions and the sub-divisions like the Länder and municipalities have to carry the financial burden without being compensated. We find similar phenomena already in Europe. For instance, my uncle who is a part-time farmer in the Bavarian Alps receives every year a substantial amount for cutting the grass only once a year (that means for doing nothing) and so protecting the variety of mountain flowers in this region. It is not the Bavarian 
government which made this environmental positive decision. It is rather based on a EC regulation. But the Bavarian government has to pay this "non-cutting grass compensation" out of own funds. In such systems it becomes totally unclear for the citizen who is really responsible for all the effects, positive ones and negative ones, of a political decision made.

\section{b) Evaluation of powers (intensity of expenses)}

It is not sufficient to know which competences the Union will have but it is equally relevant to know the size of resources needed in order to put life into these powers. This is necessary because only if we know how much money is needed we are able to determine whether a certain source or several sources of receipts will be adequate to finance the Union's budget. In this respect we have to differ between obligatory and ambulatory expenses of the Union. It is not sufficient to provide the Union with a minimum of income but the Union needs also additional resources in order to be able to set own priorities and own policies. In this respect, it would be recommendable that the Union's constitution contains a provision stipulating that any new competences conferred on the Union by later amendments of the constitution will be combined with a new assessment of the division of financial resources.

In general, we may differ between competences that can be fulfilled by legislating and competences that are fulfilled at a high degree by using financial resources. Legislating is not very expensive, the expenses normally only consist of overhead costs (personnel, offices, etc.). By contrast, in other cases financial resources are the means, which are used to implement certain policies. Currently the best example for such a cost-intensive competence is the common agricultural policy.

The Union is not only an economic community anymore. Its goal is more and more political. In the last ten years, the Union treaties were already substantially broadened by introducing new competences within areas like social policy (European social fund) or promotion of research and technological development. However, there are further cost- 
intensive issues on the agenda. For instance, a decision has to be made whether the member states are willing to co-operate more intensively on the field of a common foreign and security policy, what will also raise the question of financing. It is also worth to mention the issue of the cohesion fund. Contributions to poorer countries have helped in the past to improve substantially the economical and social situation of citizens living in those countries. Similar contributions will be needed in future also for new member countries. More resources are necessary, in particular, because from my point of view one of the strongest aspects legitimating the Union of European States is solidarity between them.

\section{c) Division of financial resources between federation and members}

Starting point on any considerations about the division of financial resources is the understanding that within a federal state both the federation as such as well as the members should have financial autonomy. Financial autonomy is one of the characteristics of a state as it determines the grade of independence of an entity's budget from its members. As long as the European Union is not financially autonomous it will remain a rather intergovernmental body. In this respect, it is not sufficient to rely on own resources. Rather the Union should have the leeway to determine the amount of own resources within certain constitutional limits.

The call for financial autonomy of the Union is not only founded on rational and practical considerations. It is rather an expression of the democratic principle. Democracy insofar means that there should be a direct link between citizens on the one hand and the responsibility for income and expenses on the other hand. Financing the budget of a state through own taxes and charges is therefore one of the main aspects of democracy. Thus, in order to make the Union more democratic, it is not sufficient to discuss whether the European Parliament should have more direct influence on European legislation or whether the Union needs institutions the decisions of which are more transparent and legitimated by the European people, it is also crucial that the Union disposes on own tax- 
raising powers. It is not only "no taxation without representation" what we as European citizens have to ask for, we also should call for "no representation without taxation".

\section{A new system of contributions}

Modifications of the present system of contributions could occur in different ways. One could introduce new own resources either in addition to the existing ones or as a replacement of some or all of them. There are good reasons first to keep the existing real own resources and to abolish the grants provided nowadays by the member states.

The current system of financing the Union's budget faces several shortcomings. The traditional own resources, the size of which can hardly be influenced by the Union itself but which have the advantage that they are at least not negotiable between the Member States, are loosing importance. The worldwide developments towards more free trade, makes it impossible in future to use customs fees and similar charges as an instrument for raising higher income. It is therefore necessary to exploit other sources of revenue.

The current grants of member states should be returned to them. In respect of the VATbased resources it was already mentioned that the yield is declining and that the uniform rate of call is subject to severe conflicts between member states that could be avoided in future by returning them back to them. The GNP resource makes the Union dependent on the economic growth in Member States (if the financial situation of member states is bad also the financial situation of the EC will be bad). The economic development, however, is frequently not predictable. In addition, the GNP-based contributions suffer from the technical difficulties in respect of estimating the total value of the national income of a country (the approaches are still different in member states and efforts to harmonize them have not been successful).

In place of the existing grants a European tax has to be created. Financing an European Community with own taxes is, by the way, not new. The budget of the European Steel and Coal Community was totally financed by charges on coal and steel enterprises. This 
system had without doubt positive effects on the steel and coal industry in Europe, on its competitive position but also on the conditions of workers within those industries.

New fiscal own resources consisting in a European tax will avoid all fights and tensions arising from attempts to measure net contributions of member states. The link between changes in EU expenditure and corresponding changes in national expenditure will be broken. The power of the Union to decide every year independently about tax rates will improve budgetary authority with the consequence that the Union's institutions will have full control of the expenditure and revenue side of the budget. Finally, the new own resources system will enhance political accountability and transparency to European citizens.

What we will give up is the idea that each member state should contribute to the European budget according to its respective financial power, perhaps even in a progressive form as supported by some of the South-European states. In this respect, it should be stressed, however, that such a system is characteristic for an intergovernmental organisation rather than a federal state. And a resource system without contributions of members states avoids those debates about the difference between contributions to and receipts from the EU budget, where it is often forgotten to take fully account for the benefits accruing to Member States simply because they are participating in the Union.

\section{How should an European tax be structured?}

Under this general assumption the question arises which kind of tax should be levied by the European Union and how should this tax be shaped. In general, we can formulate two requirements: first, there should be resource adequacy, i.e. the resource must have a significant yield relative to the size of the Union's budget. And second - I have already mentioned it - there should be a narrow link between the tax in question and the Union's competences. This is a tax where externalities are present which transcend national borders. 
Because of the lack of time I only want to say some words on the tax I would like to recommend as the future European tax, this is a European business tax. In order to achieve a close link between the European budget and taxpayers only those enterprises should be subjected to the European tax that are profiting from the common market and that carry the burden of acting in different taxation systems. Such a tax should therefore, other than traditional corporation taxes, not be based on the business form, i.e. not on incorporation of an enterprise.

In principle, we could also consider as a European tax the value added tax that is already harmonised in the Union to a certain degree and the amounts collected show certainly a direct link to the Union's budget in the eyes of citizens/taxpayers. But value added tax does not meet the requirement of resource adequacy as its yield exceeds by far the size of the Union's budget. It would be therefore necessary to split the tax base between the Union and the member states (a so-called modulated VAT tax as supposed by the European parliament some years ago), what makes it necessary to introduce an equalisation mechanism. In my opinion we should avoid such a mechanism as much as possible. Such mechanisms result in never ending disputes about the right base of allocation and they cause substantial administrative costs. Other taxes like, for instance, a European tax on energy would not hand in sufficient revenue. Income taxes, as I see it, should not be harmonised within the Union apart from some specific issues that have to be solved to improve European integration (like the problem of pensions in crossing border situations). Income taxes are needed by member states as an instrument to implement own economical and social policies.

From my perspective, the best solution would be a European tax on such businesses that are profiting of the internal market. It is a matter of fact that European enterprises suffer enormous compliance costs. They are subjected to numerous different law systems each with differing complicated administrative procedures. European wide active enterprises have to determine their profits in each state under different rules, face different formal tax requirements, need probably in each state own tax advisers, lawyers and accountants, etc. 
Furthermore, although accounting follows more and more European wide accepted accounting standards, tax accounting systems in member states show still substantial differences, a harmonisation of the tax accounting rules is in any case absolutely essential for the working of the common market. European businesses are still discriminated in other member states, loss compensations cross border are not possible and double taxation is frequently not avoided. The hidden costs are even higher. Corporate reorganizations, which would be essential for a stronger position of European businesses in a globalised economy, are never carried out because of prohibitive tax consequences.

Since the sixties of the last century (Neumark report, later Ruding report) scholars as well as the EC commission supported therefore a harmonisation of corporation taxes. In view of the persisting opposition of some member states the EC commission withdrew its plans in the beginning of the nineties and the recently published EC-Commission report "Towards an Internal Market without Tax Obstacles" tries to find a balanced way between the needs of the internal market and the position of those member states that consider the pure thinking about harmonisation of taxes in the Union as evil (I have, however, to clarify that under the current EC law doubts are justified - and Prof. Vogel has shown this in an article of 1993 - whether a harmonisation of corporate tax would be consistent with the subsidiarity principle). This report comes - not surprisingly - to the conclusion that a certain harmonisation of business taxation is necessary in order to improve the economic efficiency of the internal market and to strengthen the competitiveness of European businesses. In its report the commission proposes apart from some short-term measures a harmonization of the tax base of existing corporate tax systems. The commission discusses four different ways to reach this goal whereby a European corporate tax is only one of those solutions and it seems not to be the preferential one in view of the Commission. This is understandable from a political perspective. The commission is frightening that advocating own taxation powers would meet stiff opposition, at least in some member states. On the other hand, it is obvious that significant progress has been made in creating real internal market conditions in almost all areas but corporate taxation. It is primarily the Member States' governments, which are to blame for the lack of progress; in the words of a commentator: "it is ... the 
ignorance (of member states) towards European market reality" ${ }^{3}$. And market reality is that decision-making in multinational companies has become global whereas Member States' tax policies are still provincial.

A further positive aspect of such a tax could be that it would complement the harmonisation of company law in Europe. In Nice (2000) member states approved the statute of a European stock-corporation (Societas Europaea - SE); from 2004 on interested enterprises may use this business form. There are still substantial tax obstacles in most member countries, which make the founding of such a European corporation unattractive. Certainly, those problems could be solved without a European harmonised tax but under a common system the incorporation would be easier and more attractive.

Finally, the issue of harmful tax competition between member states in order to attract foreign businesses by offering preferential tax regimes will disappear. Of course, whether this is seen as positive or negative depends on the opinion about whether tax competition between states is healthy or harmful. In particular, economists argue that harmonisation of corporate taxes was not desirable as tax competition would disappear. This is certainly true but it is not really an argument against a European business tax. Real tax competition presupposes that the competition is fair. This was not always the case in Europe in the past. If there will not be any harmonisation on European level at least some member states would be urged to implement national measures against tax dumping. Those rules, however, are typically complicated and the legislator will always run the risk to discriminate foreign enterprises. Furthermore, the so-called code of conduct wherein the member states obliged themselves to stop unfair tax competition seen in context with the reports of the code-of-conduct-group and the application of the state aid rules result in a prohibition of introducing any new preferential tax regimes, to attract foreign businesses. A good example is the Dutch regime for financing companies of multinationals, which enjoyed substantial tax privileges if they were prepared to settle in the Netherlands. Although the provision is under attack of the commission for a long time the Dutch government tries to keep it. It is only some weeks ago that the Dutch under-minister of

O. Thömmes, Intertax 2002, 123 . 
finance declared that the regime will not be applied anymore but he seems not to be prepared to abolish the system. The Dutch government is in a difficult situation. On the one hand, it has no tax sovereignty anymore, at least not in the field of business taxation; on the other hand it would still like to use the corporation tax as an economic instrument.

It is this loss of political creative freedom why the argument member states needed the tax for using it as a financial-economic instrument has lost importance. In order to improve the business climate in respect of taxation the only way out will be to lower corporation tax rates generally with all the negative consequences for the budget of the member state. In addition, corporation tax is in some countries more important as a resource for financing the budget than in other states so that it will be easier for some countries to lower the corporation tax than for other countries. For instance, corporation tax in Austria contributes at 3 per cent to total tax revenues whereas in Luxembourg it is nearly $12 \%$. The European legislator, however, when creating a European business tax will be able first to work with a general relatively low tax rate and will have the possibility to use the tax as an economic instrument without distorting competition between member states.

\section{Conclusions}

It is true, a lot of a research has still to be done. We have to describe the criteria under which an enterprise will fall under the new European regime. Tax accounting rules have to be developed which pick up the best solutions found in the existing systems worldwide. A tax consolidation system has to be created which allows those enterprises the cross-border consolidation of losses. The Union will have to conclude tax treaties with third countries in order to avoid double taxation, best on ground of a European model tax convention. As the tax should be administered through the Member States, a legal system has to be found where it is ensured that collection of taxes occur in an efficient way. 
The new constitution should at least set the points, because otherwise any progress in respect of business taxation will be very difficult to achieve (as it seems that the existing requirement of unanimity in tax matters will remain). It is a unique opportunity to solve several problems at the same time. We would get a sound and democratic financing system within the Union, which can be expected to last for a longer time. And European businesses will be eased from all the burdens caused by 25 different tax systems.

Ladies and gentlemen, I am at the end of my lecture.

As it is customary, I would like to say some words of thanks.

First of all, I would like to thank the management and the faculty of law of this University for the confidence in my person. I will try to do the best to fulfil the expectations.

Second, I would like to express my gratitude to all the members of the capgroep belastingrecht including our secretaries. I was welcomed and integrated in such a kind way. I hope I will be able to give back a little bit of this gift.

Third, I would like to thank Prof. Vogel from whom I learned so much and who always was and is for me a shining example of how a "Hochschullehrer" should be.

Last but not least, I have to say thank you to my family. My parents and parents-in-law who always supported me if it was necessary. And I have to say thank you to you Gudrun, Sophie and Ferdinand. What would I be without you.

Ik heb gezegd. 